\title{
ESTRUTURAS GEOELÉTRICAS CRUSTAIS DO PANTANAL E FAIXA PARAGUAI: IMPLICAÇÕES TECTÔNICAS
}

\author{
Shimeles Fisseha \\ Orientador: Dra. Naomi Ussami (IAG-USP) \\ Co-Orientador: Dr. Antonio Lopes Padilha (DGE-INPE) \\ $189 p$ - Tese (Doutorado) - Defesa 29.08.2003
}

\begin{abstract}
RESUMO. A Faixa Paraguai localiza-se nos limites cratônicos dos blocos Amazônico e Paraná sob a vasta cobertura sedimentar cenozóica da Bacia do Pantanal. Esta cobertura impede que os limites não sejam precisamente definidos e constituem um dos principais problemas no entendimento da evolução geológica e tectônica da Plataforma Sul-Americana. A profundidade do embasamento e as estruturas da Bacia do Pantanal também são pouco conhecidas. Visando fornecer informações geofísicas adicionais para ajudar a resolver estes problemas geológicos, foi realizado um estudo magnetotelúrico (MT) de alta resolução na Bacia do Pantanal e segmento norte da Faixa Paraguai, onde as unidades estão expostas. Dados MT de banda larga, no intervalo de frequêencias de 100 a $0,006 \mathrm{~Hz}$, e audiomagnetotelúricos (AMT), no intervalo de $1000 \mathrm{a} 1 \mathrm{~Hz}$, foram coletados e analisados ao longo de um perfil de orientação NE - SW, entre as cidades de Corumbá e Coxim, e outro perfil de orientação WNW - ESSE, entre as cidades de Barra dos Bugres e Poxoréo. Os resultados de AMT mostraram que a Bacia do Pantanal possui uma geometria assimétrica de meiograben, com polaridade para oeste. A profundidade máxima da bacia alcança até $800 \mathrm{~m}$, próximo ao Rio Paraguai. Na maior parte da bacia, a profundidade média do embasamento varia entre 250 e $500 \mathrm{~m}$. As posições de diversas falhas foram obtidas com base no modelo de inversão. Estas falhas foram interpretadas anteriormente, a partir de dados sísmicos, como indicadores de que a subsidência da Bacia do Pantanal foi provocada pela reativação do embasamento, devido ao soerguimento e extensão flexural causada pela ombreira sub-Andina. Variações laterais de resistividade na parte superior da bacia são atribuídas à mudança na proveniência e transporte dos sedimentos durante a fase da deposição, inicialmente de oeste e subseqüentemente de leste. Esta observação é compatível com o modelo de migração da ombreira de oeste para leste, controlando os processos deposicionais na depressão do Pantanal. As análises dos dados MT de banda larga, incluindo estudos de dimensionalidade e inversão 2D, mostraram a presença de uma zona claramente anômala, marcada por uma forte anisotropia elétrica e por uma baixa resistividade elétrica ( $<50$ ohm.m), na parte central da planície do Pantanal em profundidades maiores que $6 \mathrm{~km}$. Variações na função de transferência geomagnética local, apresentadas na forma de vetores de indução, também indicam a presença desta anomalia na crosta média. Numa interpretação conjunta com dados gravimétricos, estes condutores crustais foram atribuídos à presença de metassedimentos grafitizados e/ou fluídos mineralizados em fraturas crustais profundas, enquanto as anomalias gravimétricas foram associadas a arcos magmáticos e/ou crosta inferior alçada ao longo da zona de colisão (sutura) entre dois blocos crustais com parâmetros petrofisicamente distintos. No quadro da geologia regional, estes blocos crustais a oeste e leste são atribuídos respectivamente ao cráton Rio Apa e ao Bloco Paraná. As assinaturas geofísicas profundas desta zona de colisão reforçam a hipótese de uma possível continuação para norte da faixa Pampeana, como Faixa orogênica Paraguai, sob as coberturas sedimentares do Pantanal.
\end{abstract}

ABSTRACT. The Paraguay fold belt and the actual positions of the Amazonian/Paraná cratonic borders under the vast Cenozoic sedimentary cover of the Pantanal Wetland are still unresolved and constitute a major problem in understanding the geological and tectonic evolution of the central and southern South American Platform. Moreover, the depth to the basement and other structural information of the Pantanal wetland basin are still poorly known. In order to provide further geophysical constraints to help solving these geological uncertainties, we carried out a high resolution magnetotelluric (MT/AMT) study within the Pantanal basin and over the exposed northern segment of the Paraguay fold belt. MT data in the broadband frequencies of $100 \mathrm{~Hz}$ to $0.006 \mathrm{~Hz}$ and the audiofrequencies of $1000 \mathrm{~Hz}$ to $1 \mathrm{~Hz}$ were collected and analyzed along a NE - SW profile between the towns of Corumbá and Coxim and along a WNW-ESE profile between the towns of Barra dos Bugres and Poxoréo. The AMT study has shown that the Pantanal basin exhibits a half graben geometry with a polarity towards the west. The maximum basin depth reaches $800 \mathrm{~m}$ in the vicinity of the Paraguay River. The average depth of the basement along the entire profile ranges between 250 and $500 \mathrm{~m}$. The locations of possible fault planes were inferred from the inversion model. The presence of these faults was previously interpreted, based on seismic data, as indicators that the Pantanal basin subsidence initiated through reactivation of the basement due to flexural uplift and extension caused by the sub- Andean foreland peripheral bulges. The lateral variation of resistivity in the upper part of the basin is attributed to change of provenance and transport of sediments during the course of deposition, initially from the western border, then subsequently shifting to the eastern border. This observation is compatible with a model of eastward bulge migration controlling depositional processes. The analyses of the broadband MT data, including dimensionality studies and 2D inversion, have indicated the presence of a prominent electrical resistivity anomaly, $(<50$ ohm.m) and strong electrical anisotropy in central Pantanal basin at depths beyond $6 \mathrm{~km}$. Variations in the local geomagnetic transfer function, shown as induction vectors, have further strengthened the presence of these mid-crustal conductors. In a joint interpretation with gravity data, these crustal conductors are attributed to a suture zone related to graphitized metasediments and/or circulation of mineralized fluids in mid crustal fractures whereas the gravity anomaly is thought to be caused either by remnants of squeezed magmatic-arc terranes and/or by an overthrusted lower crust, along a collisional boundary between two petrophysically distinct crustal blocks. Within the framework of the regional geology, the western and eastern blocks are attributed to the Rio Apa Craton and the Paraná block, respectively. The deeper geophysical signature of this collisional boundary reinforces previous suggestion of a northward continuation of the Pampean belt (as Paraguay orogenic belt) under the Pantanal sedimentary cover. 